\title{
PENINGKATAN HASIL BELAJAR PADA TEMA KARAKTERISTIK GEOGRAFIS INDONESIA DI KELAS V SEKOLAH DASAR MENGGUNAKAN MODEL MIND MAPPING
}

\begin{abstract}
Bayu Purbha Sakti
Universitas Widya Dharma Klaten

Jln.Ki Hajar Dewantoro Klaten Utara, Kabupaten Klaten, Jawa Tengah Corresponding Author: bavups@unwidha.ac.id

Sejarah Artikel:

Diterima: 27/09/2020

Direvisi: 29/09/2020

Disetujui:01/10/2020

Keywords: mapping learning Indonesia's geographic characteristics

\section{Abstract}

The teacher still uses the conventional learning model even though the fifth grade private primary school teacher in Bayat has implemented the 2013 curriculum. The implementation of learning carried out in the classroom is still one way where the teacher is the learning center while the students only record what the teacher says. The material to be studied is the theme of Indonesia's geographic characteristics because this theme is taught in fifth grade. Mind mapping learning model is a learning model used by students to be able to be creative in mind producing ideas or thoughts and noting what must be learned. This study used a classroom model action research model of Kemmis \& McTaggart. This study uses two cycles. Data analysis model, obtained from evaluation, interview, and observation. The use of the mind mapping learning outcomes, model is proven to improve learning outcomes in the theme of Indonesia's geographic characteristics in grade $V$ students in private elementary schools. The private primary school chosen is SD Kanisius Bayat. The learning outcomes obtained in the first cycle were the average value increased to 73.8 and were included in the criteria for $68.2 \%$. The learning outcomes obtained in the second cycle increased again to 82.3 in the high criteria with a percentage of $100 \%$. Improved material learning outcomes in Indonesia's geographic characteristics because teachers use the mind mapping model.
\end{abstract}

\begin{abstract}
Abstrak
Guru masih menggunakan model pembelajaran yang konvensional meskipun guru kelas $\mathrm{V}$ sekolah dasar swasta di Bayat sudah menerapkan kurikulum 2013. Pelaksanaan pembelajaran yang dilakukan di kelas masih bersifat satu arah dimana guru sebagai pusat belajar sedangkan siswa hanya mencatat apa yang disampaikan guru. Materi yang akan diteliti yaitu tema karakteristik geografis indonesia karena tema ini diajarkan di kelas lima. Model pembelajaran mind mapping adalah model belajar yang digunakan siswa supaya mampu menjadi kreatif dalam menghasilkan suatu gagasan atau pikiran dan mencatat apa yang harus dipelajari. Penelitian ini menggunakan penelitian tindakan kelas model Kemmis \& McTaggart. Penelitian ini menggunakan dua siklus. Analisis data didapatkan dari evaluasi, wawancara, dan observasi. Penggunaan model pembelajaran mind mapping terbukti dapat meningkatkan hasil belajar tema karakteristik geografis Indonesia pada siswa kelas V di sekolah dasar swasta. Sekolah dasar swasta yang dipilih adalah SD Kanisius Bayat. Hasil belajar yang didapatkan pada siklus I yaitu rata-rata nilai meningkat menjadi 73,8 dan termasuk dalam kriteria $68,2 \%$. Hasil belajar yang didapatkan pada siklus II yaitu meningkat lagi menjadi 82,3 berada pada kriteria tinggi dengan presentase sebesar $100 \%$. Peningkatan hasil belajar materi pada karakteristik geografis Indonesia karena guru menggunakan model mind mappping.
\end{abstract}

\footnotetext{
"Alamat korespondensi:

Universitas Widya Dharma

Jln.Ki Hajar Dewantoro Klaten Utara, Kabupaten Klaten, Jawa

(C) 2020 Program Studi PGSD Universitas Flores

Tengah.

E-mail : bayups@unwidha.ac.id
} 


\section{PENDAHULUAN}

Tujuan pendidikan tidaklah mudah dicapai karena ada proses yang dibutuhkan tidak terlepas dari peran seorang guru. Undang-undang Nomor 14 Tahun 2005 tentang guru dan dosen menjelaskan bahwa guru adalah pendidik profesional dengan tugas utama mendidik, mengajar, membimbing, mengarahkan, melatih, menilai dan mengevaluasi siswa pada pendidikan anak usia dini jalur pendidikan formal, pendidikan dasar dan pendidikan menengah. Tujuan pendidikan yang dilakukan pada zaman sekarang semakin tidak mudah karena banyak hal belajar yang dipengaruhi oleh globalisasi. Pendidikan yang dilakukan di sekolah berkaitan dengan era globalisasi (Sakti, 2020b).

Guru dituntut berperan aktif dalam mengembangkan pengetahuan dan memberikan contoh sikap yang baik sesuai dengan norma yang berlaku (Sakti, 2020a). Guru tidak lagi sebagai satu-satunya sumber belajar melainkan sebagai fasilitator dan memberikan bimbingan kepada siswa agar mampu berkembang dengan maksimal. Namun masih banyak hambatan yang dialami oleh guru dalam menerapkan pembelajaran yang menarik, efisien dan berkualitas sehingga siswa menjadi aktif baik ketika bertanya maupun dalam bekerjasama dalam kelompok.

Pada kegiatan belajar dapat ditemui hambatan. Hambatan yang ditemui guru pada umumnya adalah kurangnya melakukan variasi dalam kegiatan pembelajaran. Guru selalu menggunakan model ceramah dan kurang berinteraksi dengan siswa sehingga siswa merasa bosan dan kurang tertarik terhadap pelajaran yang diberikan. Hal tersebut dibuktikan dengan banyaknya siswa yang mengantuk, melamun ketika guru sedang menjelaskan suatu materi sehingga siswa tidak dapat menyerap ilmu yang diberikan secara maksimal.

Pembelajaran yang dilaksanakan di sekolah dasar adalah pembelajaran tematik berdasarkan Kurikulum 2013 (Sakti \& Budiyono, 2019). Guru masih menggunakan model pembelajaran yang konvensional dan ceramah meskipun kelas V di SD Kanisius Bayat sudah menerapkan kurikulum 2013.
Pelaksanaan pembelajaran di kelas masih bersifat satu arah dimana guru sebagai sumber, penyedia, dan pemberi informasi (konvensional), sedangkan siswa hanya mencatat apa yang disampaikan guru. Siswa kurang memperhatikan penjelasan guru di depan kelas bahkan siswa cenderung bosan dengan penjelasan dari guru.

Tanggung jawab guru sekolah dasar tidak hanya mengajar tetapi juga mendidik dan sekaligus berperan sebagai pembimbing yang memberi arahan dan membimbing siswa dalam belajar (Sakti, 2019). Hasil belajar siswa akan menjadi bermasalah jika siswa tidak melakukan perubahan yang lebih baik dari pengalaman yang dialaminya. Belajar adalah suatu proses usaha yang dilakukan seseorang untuk memperoleh suatu perubahan tingkah laku yang baru secara keseluruhan sebagai hasil pengalamannya sendiri dalam interaksi dengan lingkungannya (Safiudin, 2020).

Ada cara yang digunakan melatih siswa untuk memahami konsep pelajaran IPS dengan lebih baik. Salah satu model yang sekarang ini sedang berkembang dan diduga mampu membantu siswa untuk mengingat dan memahami dengan lebih baik adalah dengan menggunakan model mind map (Pemetaan Pikiran). Mind mapping merupakan salah satu model pembelajaran dimana siswa mampu menjadi kreatif dalam menghasilkan suatu gagasan atau pikiran, mencatat apa yang harus dipelajari (Zulfia Latifah, Hidayat, Mulyani, Siti Fatimah, \& Sholihat, 2020).

Tema yang akan diajarkan membutuhkan perencanaan dan kesiapan dari guru. Guru diharapkan secara kooperatif merencanakan konten, menetapkan tujuan pembelajaran, baik proses, keterampilan, maupun konten pengetahuan seputar tema (Sakti \& Budiyono, 2020). Tema yang diajarkan ke siswa telah ditulis di buku tematik. Buku pelajaran yang digunakan di sekolah dasar akan menentukan pola pikir siswa sekolah dasar (Sakti, 2018).

Materi yang akan diteliti yaitu tema karakteristik geografis indonesia karena tema ini diajarkan di kelas lima. Letak geografis adalah letak suatu daerah dilihat dari kenyataannya di bumi atau posisi daerah itu 
pada bola bumi dibandingkan dengan posisi daerah lain (Astana, 2018). Indonesia diletakkan berada di antara Benua Asia dan Benua Australia, serta di antara Samudera Hindia dan Samudera Pasifik berdasarkan letak geografis. Karakter geografis Indonesia dipengaruhi oleh angin yang bertiup dari Asia ke Australia yang membawa banyak uap air dari Samudra Pasifik sehingga menimbulkan musim hujan pada bulan Oktober menuju April. Karakter geografis Indonesia dipengaruhi oleh angin yang bertiup dari Australia ke Asia yang membawa sedikit uap air dari Samudra Hindia sehingga menimbulkan musim kemarau pada bulan April menuju Oktober.

Penggunaan mind map sebenarnya tidak hanya berhenti pada hal memahami dan mengingat saja. Justru ada begitu banyak aspek proses kognitif berdasarkan taksonomi Bloom yang terdiri dari kemampuan mengingat, memahami, mengaplikasi, menganalisis, mengevaluasi, hingga mencipta untuk perkembangan siswa yang dapat dikembangkan dengan menggunakan model pembelajaran mind map ini. Berdasarkan halhal di atas, model mind map dapat digunakan untuk membantu siswa dalam memahami, mengorganisasikan dan memvisualisasikan materi dan aktivitas belajarnya secara kreatif dan atraktif.

\section{METODE PENELITIAN}

Jenis penelitian yang akan digunakan dalam penelitian ini adalah Penelitian Tindakan Kelas. Penelitian ini menggunakan penelitian model Kemmis \& McTaggart yang memiliki empat komponen pokok yaitu a) perencanaan (planning), b) tindakan (acting), c) pengamatan (observing), dan d) refleksi (reflecting) dilaksanakan dalam beberapa siklus. Kompetensi dasar yang digunakan dalam siklus I dan II adalah mengidentifikasi karakteristik geografis Indonesia sebagai negara kepulauan/maritim dan agraris serta pengaruhnya terhadap kehidupan ekonomi, sosial, budaya, komunikasi, serta transportasi. Jika pada siklus I belum sesuai dengan kriteria keberhasilan yang ditetapkan maka penelitian dilanjutkan ke siklus II dan seterusnya sampai mengalami peningkatan.
Peneliti menggunakan teknik analisis data secara kuantitatif dan kualitatif. Analisis data yang dilakukan dengan model kuantitatif untuk mengevaluasi hasil belajar siswa setiap akhir siklus. Analisis data yang dilakukan dengan model kualitatif yaitu hasil wawancara dan observasi dianalisis menggunakan model kualitatif.

\section{HASIL DAN PEMBAHASAN}

\section{Siklus I}

Pada tahap perencanaan dimulai dari mengajukan permohonan ijin kepada kepala sekolah. Kemudian peneliti bekerja sama dengan guru kelas melakukan penemuan masalah dan kemudian merancang tindakan yang dilakukan, seperti:

1. Melakukan observasi pada siswa kelas V di SD Kanisius Bayat untuk mengetahui bagaimana kondisi dan karateristik siswa.

2. Melakukan wawancara kepada guru kelas V di SD Kanisius Bayat untuk mengetahui kondisi awal dan permasalahan yang dialami ketika dikelas.

3. Mengkaji materi sesuai dengan kompetensi inti dan kompetensi dasar.

4. Merumuskan masalah.

5. Menyusun Rencana Pelaksanaan Pembelajaran, Lembar Kerja Siswa, dan Instrumen penelitian.

Ada beberapa hasil kesepakatan dari diskusi dengan guru kelas V. Guru kelas V SD Kanisius Bayat dan peneliti berkolaborasi dalam penelitian ini untuk meningkatkan hasil belajar tema karakteristik geografis Indonesia. Tugas dari guru kelas $\mathrm{V}$ yaitu menerangkan tentang tema karakteristik geografis Indonesia sebagai negara kepulauan/maritim dan agraris serta pengaruhnya terhadap kehidupan ekonomi, sosial, budaya, komunikasi, serta transportasi serta peneliti membantu menerangkan cara membuat mind map. Materi yang dijelaskan adalah letak geografis Indonesia serta pengaruhnya. Selain itu, dijelaskan pula tentang model mind map yang nantinya akan digunakan. Waktu penelitian disesuaikan dengan jadwal pembelajaran di kelas. 


\section{Tahap Persiapan Siklus I}

Persiapan yang dilakukan peneliti serta guru pada pertemuan yaitu menyiapakan lembar materi pembelajaran pertama yaitu tema 9 sub tema 1 tentang karakteristik geografis Indonesia sebagai negara kepulauan/maritim dan agraris serta pengaruh positif terhadap kehidupan ekonomi, sosial, budaya, komunikasi, serta transportasi yang nantinya akan dibagikan kepada siswa.

Selain aktivitas di atas, peneliti serta guru juga menyiapkan perlengkapan untuk membuat mind map yaitu kertas gambar, pensil warna, spidol, dan alat gambar lainnya. Setiap akan melaksanakan tindakan peneliti serta guru melakukan diskusi mengenai materi yang akan disampaikan kepada siswa.

Hasil diskusi tersebut yaitu pertemuan ke 1 dilakukan pada hari Selasa, 25 Februari 2020. Aktivitas dimulai pada pukul 07.00 WIB. Aktivitas dilaksanakan di ruang kelas V. Pada pertemuan ke-I peneliti berkolaborasi dengan guru kelas dalam penyampaian materi.

\section{Tindakan Siklus I}

Pertemuan pertama siklus I dilakukan pada tanggal 25 Februari 2020. Materi yang diajarkan adalah letak geografis Indonesia beserta pengaruh positif letak geografis Indonesia. Ketika guru dan peneliti mulai memasuki kelas, beberapa siswa sedang sibuk menyiapakan alat tulis dan buku pelajaran. Sebelum pembelajaran dimulai, guru memperkenalkan peneliti yang akan membantu dan menemani selama proses pembelajaran . Secara lebih rinci aktivitas yang dilakukan pada pertemuan pertama sebagai berikut:

\section{Kegiatan Pembuka Siklus I}

Guru bersama peneliti memasuki ruang kelas V SD Kanisius Bayat pada pukul 07.00 WIB. Langkah awal tahap ini adalah guru mengkondisikan siswa agar siap mengikuti pembelajaran. Guru memulai pelajaran dengan mengucapkan salam kepada siswa. Semua siswa menjawab salam kemudian dilanjutkan dengan berdoa. Tidak lupa guru melakukan presensi kepada siswa. Kemudian guru melakukan apersepsi berupa aktivitas tanya jawab tentang letak geografis Indonesia yang pernah diketahui oleh siswa. Tujuan aktivitas apersepsi ini adalah untuk menggali pengalaman siswa tentang letak geografis Indonesia.

Kemudian guru memberikan penjelasan mengenai aktivitas belajar mengajar yang hendak dilaksanakan yaitu letak geografis Indonesia beserta pengaruhnya. Di samping itu, guru juga menyampaikan manfaat pembelajaran. Guru kemudian menjelaskan tujuan yang ingin dicapai dari proses pembelajaran pada hari itu. Tujuan yang ingin dicapai sebagai berikut: 1) menjelaskan letak geografis Indonesia 2) Menjelaskan pengaruh positif letak geografis Indonesia dalam bidang ekonomi, sosial, budaya, komunikasi, serta transportasi.

\section{Kegiatan Inti Siklus I}

Guru membagikan lembar materi pada siswa. Kemudian siswa diminta untuk membaca materi yang sudah dibagikan oleh guru. Setelah semua siswa membaca materi tersebut, guru mempersiapakan pertanyaan terkait materi yang dibagikan. Guru bertanya kepada siswa, "Anak-anak, apa isi dari materi yang kalian baca tadi?" Siswa masih malumalu untuk menjawab pertanyaan guru. Kemudian guru menunjuk salah satu siswa untuk menjawab. "Letak geografis Indonesia Bu", jawaban dari seorang siswa. "Betul sekali, bacaan yang kalian baca tadi adalah tentang geografis Indonesia. Apa pengertian letak geografis itu?" guru memberikan pertanyaan lagi kepada siswa. Namun, siswa masih malu untuk menjawab pertanyaan tersebut.

Guru menyampaikan materi tentang karakteristik geografis Indonesia dan pengaruh positif terhadap kehidupan ekonomi, sosial, budaya, komunikasi, serta transportasi dengam model ceramah. Setelah siswa dirasa sudah paham dengan materi tersebut, guru dan peneliti melanjutkan penjelasan tentang langkah-langkah membuat mind map.

Adapun pembahasan tentang mind map yaitu pengertian mind map, langkah-langkah membuat mind map (alat-alat yang dibutuhkan dan cara membuat mind map), dan manfaat mind map. Tidak lupa peneliti menampilkan contoh-contoh mind map. Saat penjelasan materi berlangsung masih ada beberapa siswa 
yang terlihat gaduh, ada yang berjalan-jalan ke bangku teman lain dan ada juga yang mengobrol dengan teman, namun setelah ditegur oleh guru siswa tersebut lebih tenang dan kembali fokus pada penjelasan guru.

Selesai memberikan penjelasan tentang mind map, peneliti dan guru membagikan kertas dan pensil warna untuk digunakan dalam pembuatan mind map. Guru membagi siswa dalam kelompok yaitu terdiri dari 3-4 orang dalam setiap keompok dengan cara meminta siswa untuk membuat kelompok dengan siswa lain yang diduduk meja depan/belakang. Mula-mula peneliti memberi instruksi pada siswa untuk membuat ide utama yaitu karakteristik geografis Indonesia di tengah-tengah kertas, kemudian siswa diminta untuk menambahkan cabang-cabang gagasan. Cabang pertama yaitu pengertian letak geografis Indonesia. Kemudian siswa diminta untuk menjabarkan cabang-cabang tersebut menjadi sub-cabang, dan seterusnya dengan disertai gambar dan warna yang sesuai. Peneliti juga menyampaikan bahwa dalam pembuatan mind map tersebut, siswa diminta untuk menjabarkan cabang-cabang tersebut menjadi sub-cabang tentang letak geografis wilayah Indonesia, kemudian siswa membuat cabang kedua tentang pengaruh positif letak geografis Indonesia dengan disertai gambar/ simbol dengan warna yang sesuai. Siswa diberi waktu 20 menit untuk membuat mind map tersebut.

Saat proses membuat mind map, beberapa siswa masih terlihat bingung, terbukti ada siswa yang masih melihat pekerjaan teman lain dan beberapa siswa yang bertanya kepada teman lain. Oleh karena itu, peneliti memperlihatkan kembali contoh-contoh mind map dan membimbing siswa sesuai dengan langkah-langkah yang ada. Setelah selesai, siswa mengumpulkan hasil mind map tersebut kepada peneliti. Ketika diminta untuk maju ke depan untuk mempresentasikan hasil mind map, tidak ada satu kelompokpun yang berani untuk maju ke depan kelas. Akhirnya guru menunjuk satu kelompok sebagai perwakilan untuk mempresentasikan hasil mind map. Ketika guru meminta tanggapan dari siswa tentang hasil mind map, tidak ada seorangpun yang berani untuk memberikan tanggapan.

\section{Kegiatan Penutup Siklus I}

Setelah pembelajaran selesai, guru menutup aktivitas pada pertemuan ke-I dengan diskusi kecil membahas mengenai materi karakteristik geografis Indonesia beserta pengaruhnya. Dalam diskusi tersebut, siswa terlihat mulai memahami materi yang diajarkan dengan mind map. Dikarenakan waktu sudah habis, peneliti dan guru kelas segera menutup pembelajaran tersebut. Setelah pelajaran selesai, guru bersama peneliti kemudian melakukan diskusi mengenai hasil tindakan yang telah dilakukan pada pertemuan pertama. Dari tindakan yang telah dilakukan dipertemuan pertama, siswa sudah terlihat lebih termotivasi untuk mengikuti pelajaran di kelas.

\section{Hasil Belajar Karakteristik Geografis Indonesia Siklus I}

Pemberian soal tes hasil belajar dilakukan untuk mengetahui ada tidaknya peningkatan hasil belajar siswa setelah diberikan tindakan pada siklus I. Hasil dari soal tes ini akan memperkuat data hasil pengamatan selama proses tindakan berlangsung serta berguna untuk mempertimbangkan perlu tidaknya dilaksanakannya siklus II.

Berdasarkan tes evaluasi hasil belajar karakteristik geografis Indonesia SD Kanisius Bayat pada siklus I diperoleh data jumlah siswa yang mencapai nilai Kriteria Ketuntasan Minimal (KKM) dan siswa yang belum mencapai nilai KKM. Jumlah siswa yang mencapai KKM sebanyak 15 siswa dari 22 siswa kelas $\mathrm{V}$ dengan persentase $68,2 \%$. Sedangkan yang belum mencapai KKM sebanyak 7 orang dari 22 siswa kelas $\mathrm{V}$ dengan persentase $31,8 \%$. Nila rata-rata kelas pada siklus I yaitu 73,8.

Nilai siswa pada Pra Siklus yang belum dikenai tindakan dengan siklus I yang telah dikenai tindakan mengalami kenaikan. Nilai rata-rata kelas pada Pra Siklus 59.5 sedangkan pada siklus I mencapai 73.8. Persentase ketuntasan siswa yang sudah mencapai KKM dari seluruh siswa juga mengalami kenaikan. Pada Pra Siklus $36.3 \%$, sedangkan pada siklus I mencapai $63.7 \%$. Pada siklus I persentase ketuntasan siswa belum mencapai KKM masih 
kurang dari 70\%, sehingga penelitian dilanjutkan ke siklus II.

\section{Observasi Siklus I}

Observasi yang dilakukan dalam penelitian ini meliputi 2 bagian yaitu observasi terhadap aktivitas guru dan siswa dalam proses pembelajaran pada materi letak geografis Indonesia, batas-batas wilayah beserta pengaruh positif dan negatif terhadap letak geografis Indonesia menggunakan model mind map. Peneliti dalam hal ini bertugas mengamati aktivitas guru dan aktivitas siswa selama proses pembelajaran berlangsung. Aktivitas pengamatan bertujuan untuk mengetahui apakah pelaksanaan proses pembelajaran IPS dengan materi letak geografis Indonesia, batas-batas wilayah beserta pengaruh positif dan negatif terhadap letak geografis Indonesia menggunakan model mind map dapat menunjukkan hasil yang meningkat atau menurun. Peneliti melakukan pengamatan dengan menggunakan lembar observasi yang telah disiapkan. Adapun aktivitas pengamatan yang dilakukan selama siklus I berlangsung sebagai berikut:

Observasi Guru

Observasi aktivitas guru dilakukan selama proses pembelajaran berlangsung. Aktivitas guru terlihat dari aktivitas selama proses pembelajaran IPS dengan menerapkan model mind map. Guru sudah melaksanakan aktivitas pembelajaran dengan baik meskipun terdapat beberapa kekurangan. Pada aktivitas awal pembelajaran guru mengucapkan salam dan mengajak anak berdoa. Guru juga mengajak siswa untuk mempersiapkan alat tulis dan buku yang digunakan untuk pelajaran. Guru melakukan aktivitas apersepsi dengan cara mengajak anak menyanyikan lagu berkaitan dengan materi yang akan disampaikan. Saat kegiatan apersepsi tersebut anak-anak sudah termotivasi untuk menyanyikan walaupun beberapa siswa tidak serius saat bernyanyi. Tanya jawab juga dilakukan untuk mengulang kembali materi yang disampaikan dalam pertemuan sebelumnya, namun sebagian besar siswa masih malu-malu untuk menjawab pertanyaan dari guru.
Guru menyampaikan tujuan pembelajaran yang akan dicapai dan kegiatan yang akan dilaksanakan saat pembelajaran Guru juga melakukan aktivitas pembelajaran dan menyampaikan materi sesuai dengan kompetensi dasar. Guru melakukan aktivitas tanya jawab sesuai materi yang dibaca siswa. Namun, aktivitas tanya jawab belum terjadi secara maksimal. Siswa tampak malu untuk menjawab pertanyaan dari guru. Ketika beberapa siswa ditunjuk untuk menjawab pertanyaan guru, ada siswa yang tidak mendengarkan teman yang baru menjawab pertanyaan dari guru namun malah asyik mengobrol dengan temannya.

Pada saat aktivitas membuat mind map guru masih belum bisa maksimal dalam membimbing siswa dalam pembuatan mind map. Beberapa siswa masih terlihat bingung bagaimana cara membuat cabang-cabang mind map dan penjelasan apa saja yang harus dicantumkan dalam mind map tersebut. Guru juga sudah memberi kesempatan kepada siswa untuk berdiskusi dalam kelompok kecil walaupun masih ada kelompok yang belum bisa fokus pada aktivitas diskusi.

Di akhir pelajaran guru memberikan tugas kepada siswa untuk meringkas materi pelajaran yang akan datang. Setelah pertemuan kedua guru memberikan soal evaluasi untuk mengukur tingkat pemahaman siswa terkait materi letak geografis Indonesia, batas-batas wilayah Indonesia dan pengaruh letak geografis Indonesia dalam bidang ekonomi, komunikasi, transportasi dan sosial budaya menggunakan model mind map. Secara umum bisa dikatakan bahwa pengelolaan kelas yang dilakukan oleh guru sudah cukup baik walaupun belum optimal, sehingga masih diperlukan beberapa perbaikan untuk mengatasi kekurangan yang ada saat pembelajaran di kelas.

\section{Observasi Siswa}

Tujuan adanya observasi siswa adalah untuk mengetahui bagaimana aktivitas belajar siswa pada pembelajaran IPS menggunakan mind map dengan materi letak geografis Indonesia, batas-batas wilayah dan pengaruh letak geografis Indonesia terhadap kehidupan 
ekonomi, sosial, budaya, komunikasi, serta transportasi.

Pada siklus I, sebagian siswa masih belum siap mengikuti pelajaran dengan baik. Ketika guru melakukan tanya jawab tentang materi yang dipelajari pada hari sebelumnya, sebagian besar siswa belum berani dan belum bisa menjawab pertanyaan dari guru dengan benar. Selain itu ketika guru menanyakan materi dan tujuan pembelajaran hari sebelumnya, beberapa siswa terlihat kebingungan.

Ketika aktivitas tanya jawab tentang materi yang sudah dibaca, siswa masih malu dan tidak berani untuk menjawab pertanyaan dari guru. Bahkan beberapa siswa tidak mendengarkan dengan baik bahkan berbicara dengan teman di sebelahnya. Namun ketika guru menjelaskan materi cara membuat mind map sebagian besar siswa menyimak materi yang disampaikan dengan baik.

Guru kemudian meminta siswa untuk berkelompok terdiri 3- 4 orang tiap kelompok. Setelah itu siswa dalam kelompok diminta untuk membuat cabang utama tentang judul pelajaran hari ini yaitu tentang letak geografis Indonesia beserta pengaruh positif. Saat diskusi kelompok baru terlihat beberapa siswa terlibat aktif dan sebagian besar siswa masih bingung apa yang harus dikerjakan. Kreatifitas siswa dalam pembuatan mind map juga belum maksimal, karena mereka masih bingung bagaimana cara membuat dan materi apa saja yang harus ditulis dalam mind map. Sebagian besar siswa juga belum berani untuk mempresentasikan hasil mind map dan belum berani memberikan tanggapan terhadap hasil mind map kelompok lain. Kebanyakan siswa hanya diam saja, bahkan ada beberapa siswa yang berbicara dengan teman sekelompoknya ketika ada kelompok yang presentasi. Volume suara perwakilan kelompok yang melakukan presentasi di depan kelas juga terdengar masih lirih. Diakhir pembelajaran siswa merefleksikan dan menyimpulkan materi yang telah dipelajari secara bersama-sama di bawah bimbingan guru dengan kegiatan tanya jawab dan siswa masih belum beranu menjawab pertanyaan dari guru.

\section{Refleksi Siklus I}

Peneliti melakukan refleksi pada akhir siklus I dengan mengamati kembali nilai hasil belajar serta hasil observasi siswa dan guru dalam menerapkaan model mind map. Tujuan dari aktivitas refleksi ini adalah untuk menganalisis kekurangan yang menjadi kendala pada pelaksanaan siklus I, kemudian peneliti bersama guru menentukan langkah perbaikan yang akan diterapkan pada siklus II.

Adapun kendala- kendala yang dihadapi pada pelaksanaan siklus I adalah sebagai berikut. Siswa masih belum begitu aktif dalam pembelajaran. Beberapa hasil mind map siswa masih terlihat hampir sama dengan contoh yang diberikan. Siswa belum mengembangkaan kekreatifannya secara optimal. Siswa masih sering ditegur guru dan masih kurang memperhatikan penjelasan dari guru dan kurang serius dalam membuat mind map. Siswa masih serta kurang aktif dalam proses pembelajaran, seperti: malu bertanya kepada guru, belum berani dalam mempresentasikan hasil mind map dan memberikan tanggapan. Belum optimalnya pemakaian sarana prasarana sekolah yang digunakan peneliti sebagai pendukung.

Berdasarkan nilai hasil belajar dan hasil observasi yang telah diuraikan sebelumnya, maka peneliti beserta guru kelas mengadakan diskusi untuk membahas hasil data perbandingan Pra Siklus dengan hasil data pada siklus I. Setelah berdiskusi peneliti beserta guru kelas menyadari bahwa kenyataan kenaikan tersebut belum sesuai dengan apa yang diharapkan, meskipun anak sudah mengalami peningkatan. Selain itu, masih terdapat kendala-kendala pada siklus I yang harus diperbaiki sehingga keberhasilan yang ingin dicapai peneliti dapat terjadi. Oleh karena itu, perlu diadakan tindakan berikutnya yaitu berupa perbaikan pada siklus II.

\section{Siklus II}

Siklus II merupakan tindak lanjut dari siklus I. Tujuan diadakannya siklus II ini agar hasil belajar yang diperoleh siswa dapat memenuhi kriteria keberhasilan yang ditetapkan yaitu siswa yang memenuhi KKM dari seluruh siswa. Seperti halnya siklus I, siklus II juga dilaksanakan berdasarkan 
prosedur penelitian yaitu perencanaan, pelaksanaan tindakan, observasi, dan refleksi.

\section{Perencanaan Siklus II}

Persiapan peneliti dan guru kelas pada tindakan kali ini adalah menyiapkan materi mengenai kenampakan alam. Tidak hanya menyiapkan materi saja, peneliti serta guru kelas juga menyiapkan peralatan yang akan digunakan dalam pertemuan ke 2 pada siklus II yaitu kertas gambar hasil mind map pertemuan sebelumnya yang dikumpulkan siswa pensil warna dan lembar kerja siswa. Guru juga menyiapakan powerpoint untuk menjelaskan mind map dan menyiapakan video dengan materi kenampakan alam.

\section{Tindakan Siklus II}

Adapun pelaksanaan tindakan yang dilakukan adalah sebagai berikut.

\section{Kegiatan Pembuka Siklus II}

Guru kelas membuka aktivitas dengan salam dan mengabsen siswa dengan bertanya kepada ketua kelas siapa siswa yang tidak masuk kelas. Setelah siswa tenang, peneliti serta guru kelas menyapa siswa dan bertanya kepada siswa apakah siswa masih ingat materi yang disampaikan petemuan sebelumnya tentang letak astronomis Indonesia. Berlangsunglah aktivitas tanya jawab antara siswa guru kelas. Guru mengajak siswa untuk bangkit berdiri dan melakukan tepuk anak hebat dan mengajak untuk menyanyikan lagu kebangsaan Maju Tak Gentar. Guru juga menyelipkan nasihat untuk siswa agar selalu semangat untuk mewujudkan apa yang di citacitakan.

Pada aktivitas apersepsi, guru bertanya pada siswa, "Anak-anak tadi waktu jalan ke sekolah, kalian melihat apa saja?" Siswa yang menjawab diminta mengangkat tangan, dan yang ditunjuk berkesempatan untuk menjawab. Siswa mengatakan melihat sungai, gunung, dan warung. Guru kemudian mempersempit pertanyaan. Guru mulai bertanya tentang ciriciri sungai, gunung dan warung. Guru melakukan apersepsi untuk menjebatani dengan materi pembelajaran yang akan diajarkan. Setelah apersepsi tersebut, guru menyampaikan tujuan pembelajaran pada pertemuan tersebut yaitu: 1) menjelaskan kenampakan alam 2) menyebutkan contoh kenampakan alam alami dan buatan. Tidak lupa guru juga menjelaskan aktivitas dan tugas yang harus dilakukan siswa dalam pembelajaran pada pertemuan tersebut.

\section{Kegiatan Inti Siklus II}

Peneliti dan guru kelas mulai menjelaskan tentang materi kenampakan alam dengan memutarkan video. Pada aktivitas ini, semua siswa memperhatikan video yang diputarkan guru. Tidak ada lagi siswa yang mengobrol dengan temannya ataupun jalanjalan. Kemudian setelah dirasa cukup, guru melakukan aktivitas tanya jawab kepada siswa berdasarkan materi yang diputarkan lewat video. Interaksi guru dan siswa terjalin dengan baik. Guru melakukan kontak pandang dengan siswa dalam aktivitas tersebut. Guru juga memberikan variasi volume suara sesuai dengan situasi dan kondisi, memberikan mimik wajah dan gerak badan saat memberikan pelajaran.

Guru kemudian menunjukkan beberapa contoh gambar mind map kepada siswa pada LCD. Kemudian siswa diminta untuk membuat mind map dengan kekreatifan mereka dalam kelompok. Saat membuat mind map siswa terlihat lebih serius dan tenang dari pada pertemuan sebelumnya, hal ini mungkin disebabkan karena siswa sudah mulai memahami langkah-langkah menggunakan mind map yang benar. Dalam pertemuan siklus II terlihat sekali siswa terlihat sangat senang dan antusias dalam membuat mind map, kelaspun terasa kondusif karena tidak ada siswa yang berkeliaran serta berisik diluar perintah yang diberikan. Hasil mind map pun terlihat lebih lengkap dari pada pertemuanpertemuan sebelumnya.

Guru meminta memberikan kesempatan siswa untuk mempresentasikan hasil mind map di depan kelas. Banyak siswa yang ingin mempresentasikan hasil kerja kelompok di depan kelas, namun karena keterbatasan waktu guru menunjuk kelompok yang belum pernah presentasi untuk menunjukkan hasil mind map. Tak lupa siswa mengumpulkan hasil kerja kelompok dalam membuat mind map yang baru saja dibuat oleh siswa kepada peneliti. 


\section{Kegiatan Penutup Siklus II}

Waktu membuat mind map telah habis, semua kelompok selesai membuat mind map peneliti serta guru kelas menutup aktivitas pada tindakan siklus II dengan diskusi kecil membahas tentang baagaimana kenampakan alam di Indonesia beserta contoh-contohnya. Siswa kemudian mengerjakan soal evaluasi yang diberikan oleh guru. Siswa mengerjakan soal evaluasi secara individu. Soal evaluasi bertujuan untuk mengukur hasil belajar siswa.

Sesudah mengerjakan soal evaluasi, guru bertanya kepada siswa mengenai manfaat dari mempelajari materi tersebut dengan mind map. Siswa merasa mempelajari pelajaran IPS dengan bantuan mind map bisa meningkatkan minat belajar siswa, dan konsentrasi belajar siswa pun dapat berkembang, yang tentunya berdampak pula pada hasil belajar yang baik. Karena bel sudah berbunyi, akhirnya aktivitas pada pertemuan siklus II pun segera ditutup oleh peneliti serta guru kelas dengan berdoa.

Pada akhir pertemuan siklus II peneliti bersama guru melakukan diskusi terkait hasil tindakan yang telah dilakukan. Siswa terlihat antusias selama mengikuti pembelajaran IPS menggunakan model mind map. Hal ini terbukti dari aktivitas pembelajaran yang dilakukan oleh guru dan siswa menjadi lebih baik.

\section{Hasil Belajar Karakteristik Geografis Indonesia Siklus II}

Pada akhir aktivitas pembelajaran siklus II guru memberikan tes evaluasi kepada siswa. Tes ini bertujuan untuk mengukur peningkatan hasil belajar siswa dari siklus I ke siklus II mata pelajaran menggunakan model mind map. Berdasarkan hasil tes evaluasi belajar pada siklus II SD Kanisius Bayat dapat disimpulkan bahwa seluruh siswa sudah mencapai nilai Kriteria Ketuntasan Minimal $(\mathrm{KKM}) \leq 70$ dengan nilai tertinggi adalah 96 dan nilai terendah adalah 72 . Rata-rata hasil belajar dengan tema karakteristik geografis Indonesia siswa kelas V SD Kanisius Bayat pada siklus II adalah 82,3. Siswa yang sudah mencapai $\mathrm{KKM} \geq 70$ sebanyak 22 siswa dengan presentase sebesar $100 \%$.

\section{Observasi siklus II}

Aktivitas observasi dilakukan selama proses pembelajaran dengan tema karakteristik geografis Indonesia kelas V SD Kanisius Bayat menggunakan model mind map selama pelaksanaan siklus II. Peneliti dalam hal ini bertugas mengamati aktivitas guru dan siswa. Aktivitas pengamatan bertujuan untuk mengetahui apakah pelaksanaan proses pembelajaran dengan materi letak astronomis dan kenampakan alam menggunakan model mind map menunjukkan hasil yang meningkat atau menurun. Peneliti melakukan pengamatan menggunakan lembar observasi yang telah disiapkan sebelumnya. Adapun aktivitas pengamatan pada siklus II sebagai berikut:

\section{Observasi Guru}

Pengamatan terhadap aktivitas guru dilakukan selama proses pembelajaran berlangsung. Peneliti melihat aktivitas guru pada saat memasuki ruang kelas sampai pada akhir pembelajaran selesai. Peneliti memperhatikan penyampaian guru dalam proses pembelajaran menggunakan model mind map.

Dalam pengamatan aktivitas guru ditemukan bahwa pembelajaran dilaksanakan sesuai dengan perencanaan yang telah disusun dalam RPP. Pada aktivitas awal pembelajaran guru mengucapkan salam kemudian berdoa. Kondisi situasi belajar mengajar juga sudah dapat terkondisi dengan baik. Guru memberikan apersepsi dengan menyanyikan lagu dan melakukan tanya jawab dengan siswa sesuai dengan materi pembelajaran. Siswa sangat antusias mengikuti aktivitas apersepsi yang diberikan guru. Guru sudah menyampaikan tujuan yang akan dicapai setiap pembelajaran di kelas. Pada saat menjelaskan materi guru juga sudah menggunakan video untuk menarik perhatian siswa. Setelah pemutaran video, guru juga menguatkan penjelasan tentang materi yang di ajarakan. Pembagian kelompok juga sudah dilakukan dengan baik.

Aktivitas tanya jawab antara guru dan siswa sudah berlangsung dengan baik. Siswa sudah berani mengajukan pertanyaan apabila ada hal-hal yang kurang jelas. Siswa juga sudah berani untuk menjawab pertanyaan guru. 
Ketika aktivitas presentasi di kelas, siswa yang terlihat pendiam juga sudah berani mengajukan diri untuk presentasi di depan kelas dengan volume suara yang jelas. Siswa yang lain juga sudah aktif untuk memberikan tanggapan saat aktivitas presentasi.

Guru juga sudah memberikan penghargaan kepada siswa yang sudah berani untuk menjawab pertanyaan dan memberikan tanggapan saat pembelajaran dengan cara memberikan pujian, acungan jempol dan mengajak siswa lain untuk memberikan tepuk tangan. Berdasarkan hasil observasi guru diatas dapat disimpulkan bahwa proses pembelajaran dengan materi letak astronomis dan kenampakan alam menggunakan model mind map menunjukkan adanya peningkatan dari siklus I ke siklus II.

Observasi Siswa

Observasi dilakukan untuk mengetahui aktivitas siswa mengikuti proses pembelajaran dengan materi letak astronomis Indonesia dan kenampakan alam menggunakan model mind map. Hasil observasi siswa menunjukkan adanya peningkatan aktivitas siswa selama proses pembelajaran pada siklus II. Hal ini terlihat ketika aktivitas tanya jawab dilakukan, sebagian besar siswa sudah berani untuk menjawab pertanyaan dan mengajukan pertanyaan kepada guru. Hasil observasi aktivitas siswa juga menunjukkan bahwa hampir seluruh siswa memperhatikan video dan penjelasan dari guru tanpa ada yang berjalan-jalan atau mengobrol dengan temannya.

Pada saat ada kelompok yang presentasi hasil kerja di depan kelas, siswa sudah aktif dalam menanggapi hasil kerja kelompok tersebut dan berani bertanya kepada kelompok lain jika ada kelompok yang keliru atau hasil pekerjaannya berbeda. Keterlibatan siswa dalam diskusi antar kelompok sudah hampir merata tidak seperti pertemuan-pertemuan sebelumnya yang didominasi oleh siswa tertentu saja. Saat menunggu giliran untuk persentasi, siswa kelihatan tertib (tidak ramai) dan memperhatikan kelompok yang persentasi karena mereka berlomba-lomba untuk mendapat pensil estafet dari kelompok yang sudah persentasi untuk persentasi berikutnya.
Saat aktivitas akhir siswa dapat menyimpulkan pembelajaran bersama guru. Secara keseluruhan aktivitas siswa pada siklus II sudah mengalami peningkatan. Hal tersebut terjadi karena guru bersama dengan peneliti memperbaiki kekurangan yang terjadi di siklus I.

\section{Refleksi siklus II}

Berdasarkan hasil observasi yang telah dilakukan, peneliti menyimpulkan bahwa pelaksanaan pembelajaran materi karakteristik geografis Indonesia dengan model mind map sudah menunjukkan hasil yang optimal. Refleksi dari siklus II pada pertemuan pertama dan kedua adalah sebagai berikut. Siswa sudah menunjukkan keaktifan selama proses pembelajaran menggunakan model mind map seperti: sudah berani bertanya dan menjawab pertanyaan, memberikan tanggapan, berdiskusi dan melakukan presentasi hasil mind map. Siswa sudah mengembangkaan kekreatifannya secara optimal dalam pembuatan mind map. Dengan bantuan peta pikiran, siswa dapat membuat peta kelompok kata dengan tema berbeda dan menambahkan kata baru ke kelompok yang sesuai kapan saja (Yang, 2020). Siswa sudah bisa menyimak penjelasan dari guru dan sudah serius dalam membuat mind map. Penggunaan sarana dan prasarana sekolah sudah optimal.

Penelititian Tindakan Kelas dinyatakan berhasil ketika telah memenuhi kriteria keberhasilan yang telah di tentukan. Berdasarkan data yang diperoleh dari rata-rata hasil belajar siswa sudah mengalami peningkatan dari siklus I 73,8 atau sebesar $68,2 \%$ dan rata-rata hasil belajar siswa pada siklus II yaitu 82,3 atau sebesar $100 \%$ siswa sudah mencapai KKM atau mendapatkan nilai $\geq 70$ pada siklus II. Hal tersebut sudah mencapai kriteria keberhasilan yang telah ditentukan sebelumnya yaitu peningkatan hasil belajar siswa setiap siklus meningkat dan secara klasikal hasil belajar seluruh siswa mencapai $\mathrm{KKM} \geq 70 \%$ dari total jumlah seluruh siswa telah mencapai KKM dengan hasil belajar sekurang-kurangnya 70. Hasil penelitian pada siklus II telah mencapai indikator keberhasilan yang diinginkan. Kendala-kendala pada siklus I juga dapat diatasi dengan baik. Selain itu, berdasarkan 
hasil diskusi yang dilakukan peneliti dengan guru kelas V SD Kanisius Bayat dinyatakan bahwa langkah-langkah yang telah disusun dalam rencana pelaksanaan pembelajaran melalui model mind map sudah terlaksana dengan benar.

Setelah melihat data dari nilai hasil belajar dan observasi aktivitas belajar siswa dengan menerapkan model mind map di atas, dapat diketahui peningkatan hasil pembelajaran. Model Mind Map telah terbukti membantu seseorang lebih mudah mengingat / menghafal informasi, mengenali informasi kunci / penting, mengambil keputusan, dan merencanakan (Susanto, 2020). Peta pikiran memiliki manfaat seperti mengingat, meningkatkan kreativitas, memecahkan masalah, fokus pada suatu subjek dan mengatur pemikiran (Erdem, 2017). Penerapan model mind map dapat meningkatkan hasil belajar siswa kelas V SD Kanisius Bayat dan sudah sesuai dengan kriteria keberhasilan sehingga peneliti dapat mengakhiri penelitian di kelas tersebut.

\section{SIMPULAN DAN SARAN}

Penggunaan model pembelajaran mind map terbukti dapat meningkatkan hasil belajar tema karakteristik geografis Indonesia pada siswa kelas V di sekolah dasar swasta. Sekolah dasar swasta yang dipilih adalah SD Kanisius Bayat. Hal tersebut dibuktikan dengan adanya peningkatan pada tindakan pra siklus menunjukkan hasil rata-rata nilai sebesar 59,5 dan berada pada kriteria 36,3\%. Setelah dilakukan tindakan pada siklus I, hasil rata-rata nilai meningkat menjadi 73,8 dan termasuk dalam kriteria $68,2 \%$. Pada siklus II rata-rata hasil belajar IPS dengan tema karakteristik geografis Indonesia meningkat lagi menjadi 82,3 berada pada kriteria tinggi dengan presentase sebesar $100 \%$. Peningkatan aktivitas juga terjadi. Peningkatan hasil belajar dan aktivitas belajar mata pelajaran IPS materi karakteristik geografis Indonesia ini dikarenakan guru menggunakan model mind map dapat menjadikan pembelajaran yang menyenangkan dan menarik bagi siswa sehingga siswa menjadi aktif pada saat proses pembelajaran dan hasil belajar meningkat.

\section{DAFTAR PUSTAKA}

Astana. (2018). Kedutaan Besar Republik Indonesia di Nur-Sultan, Kazakhstan, di NUR-SULTAN, , KAZAKHSTAN. Retrieved September 25, 2020, from https://kemlu.go.id/nursultan/id/pages/geografi/41/etc-menu

Erdem, A. (2017). Mind Maps as a Lifelong Learning Tool. Universal Journal of Educational Research. Retrieved from https://eric.ed.gov/?q=Mind+Maps+as+a +Lifelong+Learning+Tool\&id=EJ116549 0

Safiudin. (2020). Peningkatan Hasil Belajar IPS Tema Keberagaman Budaya Bangsaku Melalui Pendekatan Konstruktivisme Siswa Kelas V SD Negeri 2 Kombeli Kabupaten Buton. Cokroaminoto Journal of Primary Education, 3(1), 12-22. Retrieved from https://e-journal.my.id/cjpe

Sakti, B. P. (2018). Feasibility Indicators Of Study Books Used Elementary School Students. Social, Humanities, and Educational Studies (SHEs): Conference Series. https://doi.org/10.31227/OSF.IO/5NJVK

Sakti, B. P. (2019). Student Profile Toword Course Activities At PGSD FKIP University Widya Dharma Klaten. JPDI (Jurnal Pendidikan Dasar Indonesia), 4(2), 34-45. Retrieved from https://journal.stkipsingkawang.ac.id/inde x.php/JPDI/article/view/1220

Sakti, B. P. (2020a). The Role Of Parents And Teachers In Supervising Primary School Student's Attitude Due To Influence From Technology Based On Industrial Revolution 4.0. Prosiding Seminar Nasional PBSI UPY, 1(1), 179-186. Retrieved from http://prosiding.pbsi.upy.ac.id/index.php/ 2019/article/view/26

Sakti, B. P. (2020b). Upaya Peningkatan Guru Profesional Dalam Menghadapi Pendidikan Di Era Globalisasi. Attadib: Journal of Elementary Education, 4(1), 74-83. https://doi.org/10.32507/ATTADIB.V4I1 
.632

Sakti, B. P., \& Budiyono, S. (2019). Pelaksanaan Pembelajaran Tematik Di SDN 1 Kragilan. Refleksi Edukatika: Jurnal Ilmiah Kependidikan, 10(1), 65$70 . \quad$ Retrieved from https://jurnal.umk.ac.id/index.php/RE/arti cle/view/3860

Sakti, B. P., \& Budiyono, S. (2020). Thematic Learning Implementation in Used Areas from Earthquake in Gantiwarno SubDistrict Klaten Regency. In Proceedings of the 2nd International Seminar on Guidance and Counseling 2019 (ISGC 2019) (pp. 260-264). Paris, France: Atlantis Press. https://doi.org/10.2991/assehr.k.200814.0 57

Susanto. (2020). LEARNING OBJECT: Mind Map for Success (English Version). Retrieved September 27, 2020, from https://student.binus.ac.id/2020/06/mindmap-for-success-english-version/

Yang, C. (2020). 7 Ways to Use Mind Map in Education. Retrieved September 27, 2020, from https://www.edrawsoft.com/mindmaster/ 7-ways-use-mindmap-education.html

Zulfia Latifah, A., Hidayat, H., Mulyani, H., Siti Fatimah, A., \& Sholihat, A. (2020). Penerapan Metode Mind Mapping Untuk Meningkatkan Kreativitas Pada Pembelajaran Pendidikan Kewarganegaraan. Jurnal Pendidikan, 21(1), 38-50. https://doi.org/10.33830/jp.v21i1.546.202 0 